\title{
Diagnostic accuracy of sensitive or high-sensitive troponin on presentation for myocardial infarction: a meta-analysis and systematic review
}

This article was published in the following Dove Press journal:

Vascular Health and Risk Management

21 July 2014

Number of times this article has been viewed

\author{
Ankur Sethi' \\ Anurag Bajaj² \\ Gurveen Malhotra' \\ Rohit R Arora' \\ Sandeep Khosla' \\ 'Department of Medicine, Division \\ of Cardiology, Rosalind Franklin \\ University of Medicine and Science, \\ North Chicago, IL, USA; ${ }^{2}$ Department \\ of Medicine, Wright Center of \\ Graduate Medical Education, Scranton, \\ PA, USA
}

Background: Recently, high-sensitive troponin (hsTrop) assays consistent with professional societies' recommendations became available. We aimed to summarize the evidence on the diagnostic accuracy of hsTrop on presentation.

Methods: We searched electronic databases for studies evaluating the diagnostic accuracy of hsTrop in suspected acute coronary syndrome (ACS) patients. Random effect meta-analyses and meta-regression were performed. Primary and secondary analyses were restricted to studies using conventional Trop and hsTrop in the reference standard, respectively.

Results: Fifteen studies with a total of 8,628 patients met the inclusion criteria for the primary analysis. hsTrop T (Hoffman-La Roche Ltd) and hsTrop I (Siemens) had sensitivities of 0.89 (95\% confidence interval [CI]: 0.86-0.91) and 0.90 (95\% CI: 0.87-0.92) and specificities of 0.79 (95\% CI: $0.77-0.80)$ and 0.89 (95\% CI: 0.87-0.90), respectively. There was no statistically significant difference in the area under the curve between hsTrop (95\% CI: 0.920) and conventional Trop (95\% CI: 0.929$)$ at the 99 th percentile $(P=0.62)$. hsTrop at the level of detection had a sensitivity of 0.97 (95\% CI: 0.96-0.98) and a specificity of 0.41 (95\% CI: $0.40-0.42$ ). The studies using a cut-off at coefficient of variance $<10 \%$ as opposed to the 99 th percentile for the conventional assay used for diagnosis reported higher diagnostic accuracy (relative diagnostic odds ratio $=2.13, P=0.02$ ). Five studies were included in the secondary analysis; hsTrop T (Hoffman-La Roche Ltd) had a sensitivity of 0.91 (95\% CI: $0.89-0.93)$ and a specificity of 0.67 (95\% CI: 0.63-0.70). There was significant heterogeneity among the studies.

Conclusion: hsTrop have excellent diagnostic accuracy for myocardial infarction on presentation, but may not outperform conventional Trop assays. The variation among the studies can be explained, in part, by the cut-off used for conventional Trop assays.

Keywords: high-sensitive troponin T, high-sensitive troponin I, sensitivity, specificity, level of detection

\section{Background}

Each year in the US, more than seven million people visit the emergency department with complaints of chest pain and related symptoms. ${ }^{1}$ Many such patients require further evaluation including cardiac biomarkers. Cardiac troponins T or I (Trop T or I) are the preferred biomarkers for the evaluation of such patients with suspected acute coronary syndrome (ACS). ${ }^{2}$ Trop T or I not only help in the rapid diagnosis of acute myocardial infarction (AMI), but also in risk stratification and selection of an appropriate treatment strategy. The European Society of Cardiology/American College of Cardiology/ American Heart Association/World Heart Federation (ESC/ACC/AHA/WHF) task force consensus document recommends an assay-specific cut-off of 99th percentile of
Correspondence: Ankur Sethi 3333 Green Bay Road,

North Chicago, IL 60064, USA

Tel +l $85853 \mid 9475$

Fax +I 7732576726

Email drankursethi@gmail.com 
a normal healthy population as the decision level, in addition to a rise and fall pattern, for the diagnosis of AMI. ${ }^{3,4}$ In order to reliably detect rise and fall, assays with a coefficient of variation $(\mathrm{CV})<10 \%$ at the 99 th percentile are considered to have optimal precision. ${ }^{4}$ Contemporary Trop assays lack such a precision at the 99th percentile, and therefore suffer from reduced sensitivity, especially during the early hours of AMI. To fulfill these criteria, sensitive or high-sensitive troponin (sTrop or hsTrop) assays with improved sensitivity and precision (CV $<10 \%$ at the 99th percentile) have been developed. Initial studies have reported improved diagnostic accuracy of sTrop/hsTrop (s/hsTrop) assays on presentation to the emergency room at the recommended 99th percentile cut-off., 5 Subsequent studies have proposed a novel cut-off at the level of detection (LOD) in order to achieve $100 \%$ sensitivity on the initial evaluation and rapidly rule out patients with symptoms suggestive of ACS. ${ }^{7-9}$ Although a test with high sensitivity is desired in the emergency room setting, the elevations in Trop, as measured by the s/hsTrop assays in conditions other than AMI, may significantly compromise its specificity. In order to synthesize the evidence on currently available s/hsTrop assays, we undertook a systematic review and meta-analysis to assess the diagnostic accuracy of s/hsTrop on initial presentation in patients with symptoms suggestive of ACS.

\section{Methods}

We systematically searched PubMed/MEDLINE and the EMBASE database for clinical studies evaluating the diagnostic accuracy of s/hsTrop assays in unselected patient populations suspected of ACS. The following keywords were used: "high-sensitive/sensitivity troponin", "Roche troponin", "Abbott troponin", and "Siemens troponin". The reference list of included studies and relevant review articles were hand-searched to identify additional studies. Citations with manuscripts published in peer-reviewed journals were included. Conference abstracts were excluded due to the inability to assess the relevant study characteristics. No language restrictions were imposed. The last search was performed on November 9, 2012.

For the purpose of this review, s/hsTrop assays were defined as assays with: 1) LOD $<99$ th percentile of the healthy population and 2) $\mathrm{CV} \leq 10 \%$ at the 99th percentile for the assay.

The following inclusion criteria were used: prospective, retrospective, or observational studies evaluating the diagnostic accuracy of s/hsTrop assays, as defined above, on initial presentation in unselected patients presenting with symptoms suggestive of ACS. In addition, the final diagnosis was adjudicated by a contemporary reference standard that comprised a review of the clinical data, serial Trop testing, and available supplementary investigations to diagnose or exclude AMI (or ACS) in accordance with the existing guidelines.

Exclusion criteria: studies only evaluating specific patients such as those with negative biomarkers on presentation, abnormal electrocardiogram, or undergoing invasive therapy were excluded. Also, studies using creatine kinase/ creatine kinase myocardial band for the diagnosis of AMI were excluded.

\section{Data extraction and synthesis}

Two authors (AS and AB) independently assessed all studies for inclusion in the systematic review and meta-analysis. Data on study characteristics - mean/median age, \% males, inclusion/exclusion criteria, and adjudication of diagnosis - were extracted from the included studies (Table S1). The enrollment period and study sites for the data collection were specifically noted to prevent duplication. In the presence of more than one study from the same site and enrollment period, the study with the higher number of patients and latest publication date was included. The studies reporting accuracy of more than one s/ hsTrop assay were treated as separate datasets. Among other study characteristics, inclusion of patients with ST elevation myocardial infarction (STEMI), dialysis, and prevalence of coronary artery disease (CAD) were noted. If the prevalence of CAD was not reported, then the most prevalent surrogate, ie, angina, myocardial infarction, or coronary revascularization was used. The cut-off value used for both s/hsTrop and conventional Trop assays was noted. There was a provision of third author evaluation in the case of disagreement regarding study inclusion or extracted characteristics, but no significant discordance was encountered.

The primary quantitative analysis was restricted to studies evaluating diagnostic accuracy for AMI using conventional Trop testing in the reference standard. A systematic review of studies evaluating diagnostic accuracy for ACS instead of AMI was reported separately. A secondary quantitative and qualitative analysis was performed on the studies evaluating diagnostic accuracy of s/hsTrop for AMI using serial s/hsTrop testing instead of conventional Trop in the reference standard.

\section{Statistical analysis}

Absolute numbers of true-positive, true-negative, falsepositive, and false-negative were extracted or calculated for the individual studies. From the extracted data pooled, sensitivity, specificity, and negative and positive likelihood ratio 
were calculated using the DerSimonian and Laird method (random effect model). As studies with the same diagnostic cut-off, ie, 99th percentile or LOD were used to calculate pooled estimates, threshold analysis was not undertaken.

Heterogeneity between studies was assessed using Cochran's Q test and $I^{2}$ (Inconsistency index). The source of heterogeneity among the studies was explored by performing a meta-regression of study characteristics on the diagnostic odds ratio (DOR) by using the restricted maximum likelihood method weighted by the inverse of study variance and inclusion of threshold effect in the model.

The summary receiver operating curve (SROC) was estimated with the area under the curve (AUC) as the measure of diagnostic accuracy. An AUC of 0.5 indicated poor discrimination, whereas value of 1 suggested perfect discrimination between those with and without disease. The curve was plotted on the basis of change in DOR using the DerSimonian and Laird method. The areas under the curve were compared using two-tailed $t$-tests. A $P$-value $<0.05$ was considered statistically significant. Statistical analysis was performed using Review Manager (RevMan; v5.2; The Nordic Cochrane Centre, Copenhagen, Denmark) and Meta-DiSc (v1.4; Clinical Biostatistics Unit, Ramon y Cajal Hospital, Madrid, Spain). ${ }^{10}$

The Review Manager was used for quality assessment of included studies based on the QUADAS (Quality Assessment tool for Diagnostic Accuracy Studies) questionnaire.

\section{Results}

Fifteen studies with a total of 8,628 patients met the inclusion criteria for the primary analysis as shown in Figure 1 eight studies with 3,115 patients used hsTrop T, six studies with 4,415 patients used s/hsTrop I, and one study with 1,098 patients used both hsTrop T and sTrop I. Among these studies, ten studies also reported on the diagnostic accuracy of conventional Trop assays on initial presentation at a cut-off of 99th percentile. The mean/median age was 54-67.6 years, and $49.2 \%-71.3 \%$ patients were male. Other relevant study characteristics are shown in Table S1. All hsTrop T studies used the assay manufactured by Roche (Roche High-Sensitive Troponin T; Hoffman-La Roche Ltd, Basel, Switzerland). Out of the seven studies on s/hsTrop I, four used Trop I Ultra (Siemens Healthcare Diagnostics, Erlangen, Germany), one used Architect STAT High-Sensitive Trop (Abbott Laboratories, Abbott Park, IL, USA), one used VITROS Trop I assay (Ortho-Clinical Diagnostics; Johnson \& Johnson, New Brunswick, NJ, USA), and one used Singulex Erenna Trop I (Alameda, CA, USA). Two additional studies that reported diagnostic accuracy of s/hsTrop for ACS only were identified (Table S1). Seven studies reported diagnostic accuracy of hsTrop using serial s/hsTrop assays in the reference standard and were included in the secondary analysis (Table S2).

\section{hs Trop T}

Eight out of the nine studies reported diagnostic accuracy of hsTrop $\mathrm{T}$ on presentation at a 99th percentile cut-off of a healthy population. Kurz et $\mathrm{al}^{19}$ used a different diagnostic cut-off for hsTrop T, and therefore, was not included in the calculation of pooled point estimates. The pooled sensitivity and specificity were 0.885 (95\% CI: $0.863-0.905, \chi^{2}=32.87$, $\left.P \leq 0.001, I^{2}=78.7 \%\right)$ and 0.783 (95\% CI: 0.768-0.797, $\chi^{2}=47.5, P<0.001, I^{2}=85.3 \%$ ), respectively, as shown in Figure $2 \mathrm{~A}$. The pooled positive and negative likelihood ratios were 3.999 (95\% CI: $3.360-4.760, \chi^{2}=38.6, P<0.001$, $\left.I^{2}=81.9 \%\right)$ and 0.137 (95\% CI: 0.092-0.205, $\chi^{2}=27.82$, $P<0.001, I^{2}=74.8 \%$ ), respectively (Table $1 \mathrm{~A}$ ). There was significant heterogeneity among the studies.

\section{s/hsTrop I}

The assay types were more variable in the s/hsTrop I studies. Therefore, in addition to cumulative point estimates, a subgroup analysis of studies using a sensitive assay - Siemens Trop I Ultra - was performed. The pooled sensitivity and specificity of all s/hsTrop I studies at a 99th percentile cutoff were 0.867 (95\% CI: 0.845-0.887, $\chi^{2}=43.46, P<0.001$, $\left.I^{2}=86.2 \%\right)$ and 0.879 (95\% CI: 0.869-0.888, $\chi^{2}=80.34$, $P<0.001, I^{2}=92.5 \%$ ), respectively. The pooled sensitivity and specificity of the studies using Siemens trop I Ultra were 0.899 (95\% CI: $0.874-0.886, \chi^{2}=21.62, P<0.001, I^{2}=86.1 \%$ ) and 0.886 (95\% CI: $0.874-0.898, \chi^{2}=19.26, P<0.001$, $I^{2}=84.4 \%$ ), respectively, as shown in Figure $2 \mathrm{~B}$ and Table 1. The pooled positive and negative likelihood ratios for this subgroup were 6.30 (95\% CI: 4.400-9.022, $\chi^{2}=27, P<0.001$, $\left.I^{2}=88.9 \%\right)$ and 0.135 (95\% CI: 0.067-0.269, $\chi^{2}=20.37$, $P<0.001, I^{2}=85.3 \%$ ), respectively, as shown in Table $1 \mathrm{~A}$. There was significant heterogeneity among the studies for all pooled estimates.

\section{s/hsTrop at the LOD}

Nine studies/substudies reported diagnostic accuracy of $\mathrm{s} / \mathrm{hs}$ Trop at the cut-off of LOD on presentation. Reiter et $\mathrm{al}^{21}$ did not report diagnostic accuracy at LOD. However, a prior publication from the same cohort did, ${ }^{6}$ and was included in the current analysis. The pooled sensitivity and specificity were 0.974 (95\% CI: 0.963-0.983, $\chi^{2}=44.4, P<0.001$, $\left.I^{2}=82 \%\right)$ and $0.410\left(95 \% \mathrm{CI}: 0.396-0.424, \chi^{2}=533.2\right.$, 


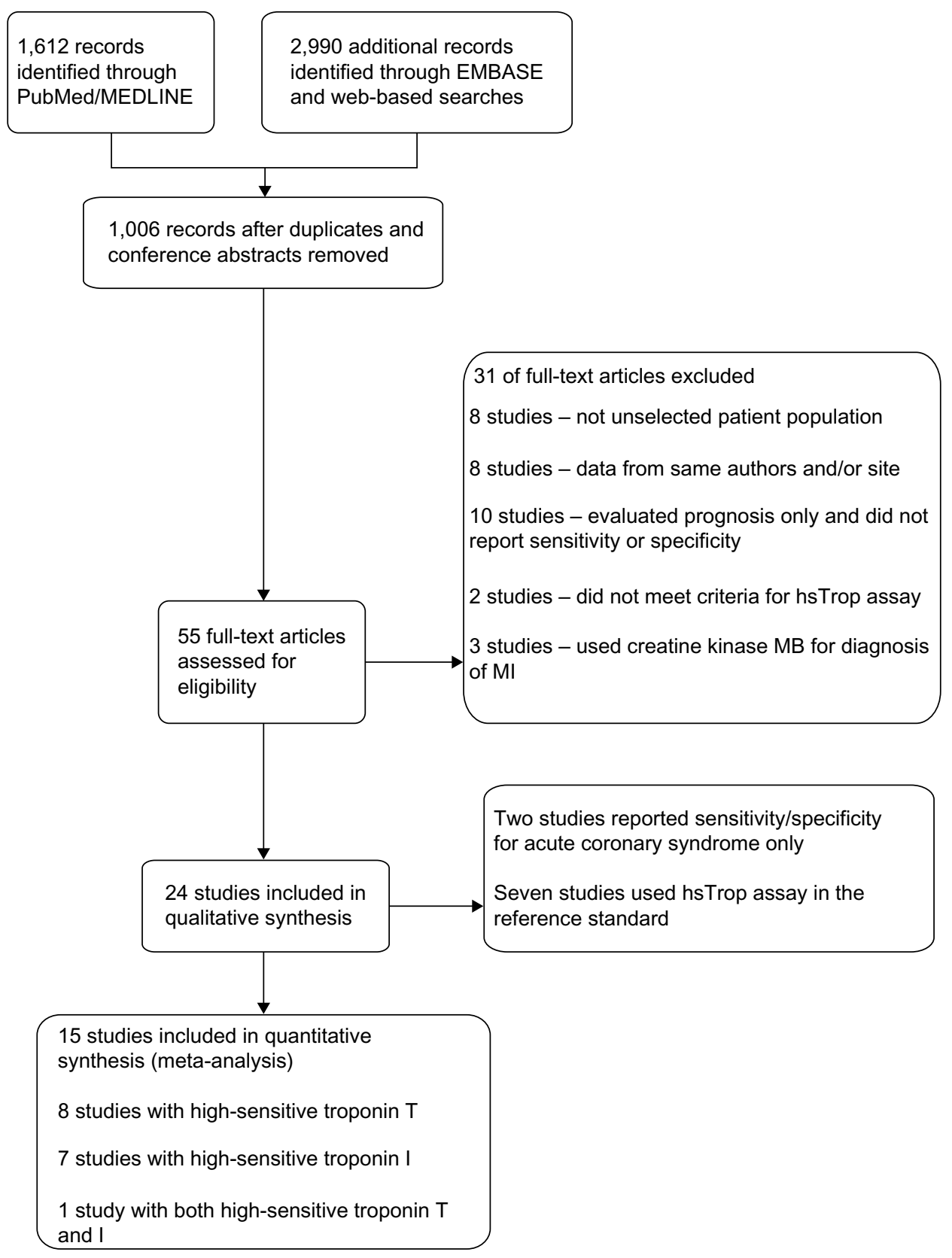

Figure I Study selection flow chart.

Abbreviations: hsTrop, high-sensitive troponin; MB, myocardial band; MI, myocardial infarction.

$\left.P<0.001, I^{2}=98.5 \%\right)$, respectively. The pooled positive and negative likelihood ratios were 1.646 (95\% CI: 1.337-2.027, $\left.\chi^{2}=609.87, P<0.001, I^{2}=98.7 \%\right)$ and $0.079(95 \% \mathrm{CI}$ : $0.042-0.148, \chi^{2}=17.45, P=0.026, I^{2}=54.1 \%$ ), respectively (Table 1).

\section{Effect of study covariates}

To explore the heterogeneity among the studies, metaregression analysis of four study level covariates: inclusion of patients with STEMI and dialysis, prevalence of CAD, and cut-off of conventional assays used to diagnose AMIs on the
DOR was performed. There was no association between diagnostic accuracy and the other three study characteristics, but use of a cut-off $\mathrm{CV}<10 \%$ for the conventional assay instead of the 99th percentile significantly improved the diagnostic accuracy of s/hsTrop on presentation as shown in Table 1B.

\section{Comparison of conventional and hsTrop}

Among the included studies, ten studies reported the diagnostic accuracy of conventional trop assays on presentation. The SROC of conventional Trop assays, s/hsTrop assays at a cut-off of 99th percentile, and the LOD is shown in Figure 3. There was 


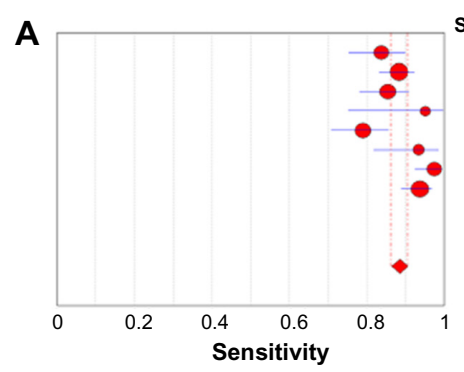

Sensitivity $(95 \% \mathrm{Cl})$

$0.84(0.75-0.90) \quad$ Aldous et al ${ }^{11}$ $0.88(0.83-0.92)$ $0.85(0.78-0.91)$ $0.95(0.75-1.00)$ $0.79(0.71-0.86)$ $0.93(0.82-0.99)$ $0.94(0.89-0.97)$

Pooled sensitivity $0.89(0.86-0.91)$

Aldous et al ${ }^{12}$ Body et $\mathrm{al}^{7}$ Christ et $\mathrm{al}^{8}$
Eggers et al
$\mathrm{l}^{11}$ Eggers et $\mathrm{al}^{11}$
Freund et $\mathrm{al}^{17}$ Melki et al ${ }^{20}$ Reiter et $\mathrm{al}^{21}$

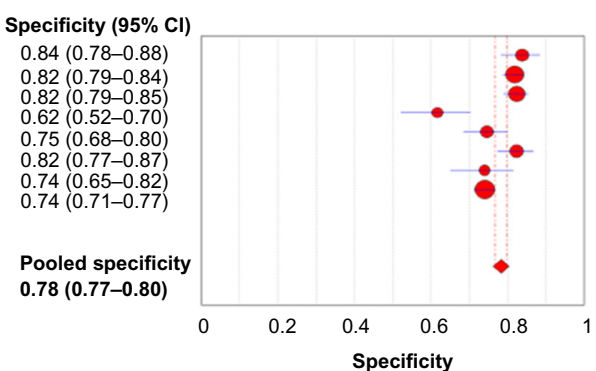

B

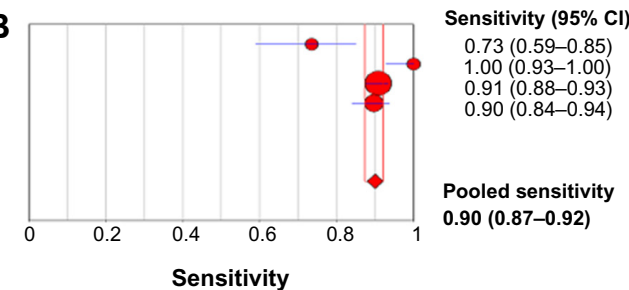

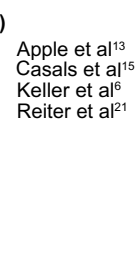

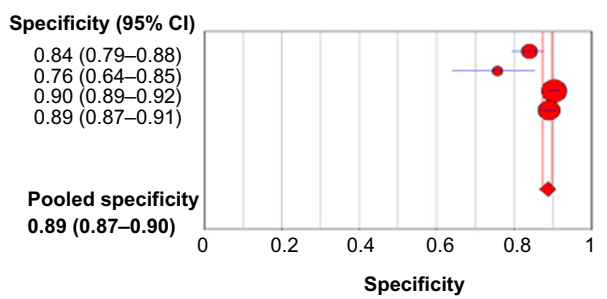

Figure 2 Forest plots showing pooled sensitivities and specificities.

Notes: (A) High-sensitive troponin T (Hoffman-La Roche Ltd) and (B) sensitive troponin I (Siemens Healthcare Diagnostics), both at 99th percentile. Data are rounded to two decimal points.

Abbreviation: $\mathrm{Cl}$, confidence interval.

no statistically significant difference between the AUC of conventional Trop and s/hsTrop at two different cut-offs.

\section{ACS}

Two studies not included in the primary analysis reported diagnostic accuracy for ACS only (Table S1). Also, Keller et $\mathrm{al}^{18}$ and Reiter et $\mathrm{al}^{21}$ reported diagnostic accuracy for ACS in addition to AMI. As shown in Figure S1, the sensitivity ranged $0.56-0.77$ and the specificity ranged $0.76-0.94$.

\section{s/hsTrop for adjudication of diagnosis}

Seven additional studies that used serial s/hsTrop testing in the reference standard, instead of conventional Trop, to diagnosis the AMI were identified (Table S2). In addition to conventional assays, Christ et $\mathrm{al}^{8}$ and Melki et $\mathrm{al}^{20}$ reported diagnostic accuracy on presentation using serial hsTrop $\mathrm{T}$ testing to diagnose AMI. Clearly, the outcomes of these studies suffer from incorporation bias. Out of these nine studies, seven used hsTrop T (Hoffman-La Roche Ltd) and two used trop I Ultra (Siemens Healthcare Diagnostics). The studies were very heterogeneous in terms of inclusion and exclusion criteria, as well as diagnostic cut-off. Kelly ${ }^{27}$ and Khan et $\mathrm{al}^{28}$ excluded patients with any alternate diagnosis and Scharnhorst et $\mathrm{al}^{31}$ used clinical diagnosis to adjudicate the AMI. The pooled sensitivity and specificity for hsTrop T (Hoffman-La Roche Ltd) on admission, after exclusion of

Table I (A) Pooled estimates of diagnostic accuracy for myocardial infarction of studies included in primary analysis; (B) results of meta-regression analysis of study level covariates on diagnostic odds ratio

(A)

\begin{tabular}{llll}
\hline Outcome & $\begin{array}{l}\text { hsTrop T (Roche) } \\
\text { at 99th percentile }\end{array}$ & $\begin{array}{l}\text { hsTrop I (Siemens) } \\
\text { at 99th percentile }\end{array}$ & $\begin{array}{l}\text { hsTrop I or T at } \\
\text { LOD }\end{array}$ \\
\hline Sensitivity $(95 \% \mathrm{Cl})$ & $0.885(0.863-0.905)$ & $0.899(0.874-0.921)$ & $0.974(0.963-0.983)$ \\
Specificity $(95 \% \mathrm{Cl})$ & $0.783(0.768-0.797)$ & $0.886(0.874-0.898)$ & $0.410(0.395-0.424)$ \\
Positive likelihood ratio $(95 \% \mathrm{Cl})$ & $3.999(3.360-4.760)$ & $6.300(4.400-9.022)$ & $1.646(1.337-2.026)$ \\
Negative likelihood ratio $(95 \% \mathrm{Cl})$ & $0.137(0.092-0.205)$ & $0.135(0.067-0.269)$ & $0.079(0.042-0.148)$ \\
(B) & & & $\mathbf{P - v a l u e}$ \\
\hline Study variable & RDOR & $95 \%$ CI & 0.469 \\
\hline Inclusion of STEMI & 1.35 & $0.58-3.16$ & 0.218 \\
Exclusion of patients with dialysis & 1.63 & $0.73-3.67$ & 0.329 \\
Prevalence of CAD & 0.11 & $0.00-10.62$ & 0.027 \\
Diagnostic cut-off $<10 \%$ CV versus 99th percentile & 2.15 & $1.10-4.21$ & \\
\hline
\end{tabular}

Abbreviations: $\mathrm{CAD}$, coronary artery disease; $\mathrm{Cl}$, confidence interval; $\mathrm{CV}$, coefficient of variance; hsTrop, high-sensitive troponin; LOD, level of detection; RDOR, relative diagnostic odds ratio; STEMI, ST elevation myocardial infarction; Roche, Hoffman-La Roche Ltd; Siemens, Siemens Healthcare Diagnostics. 


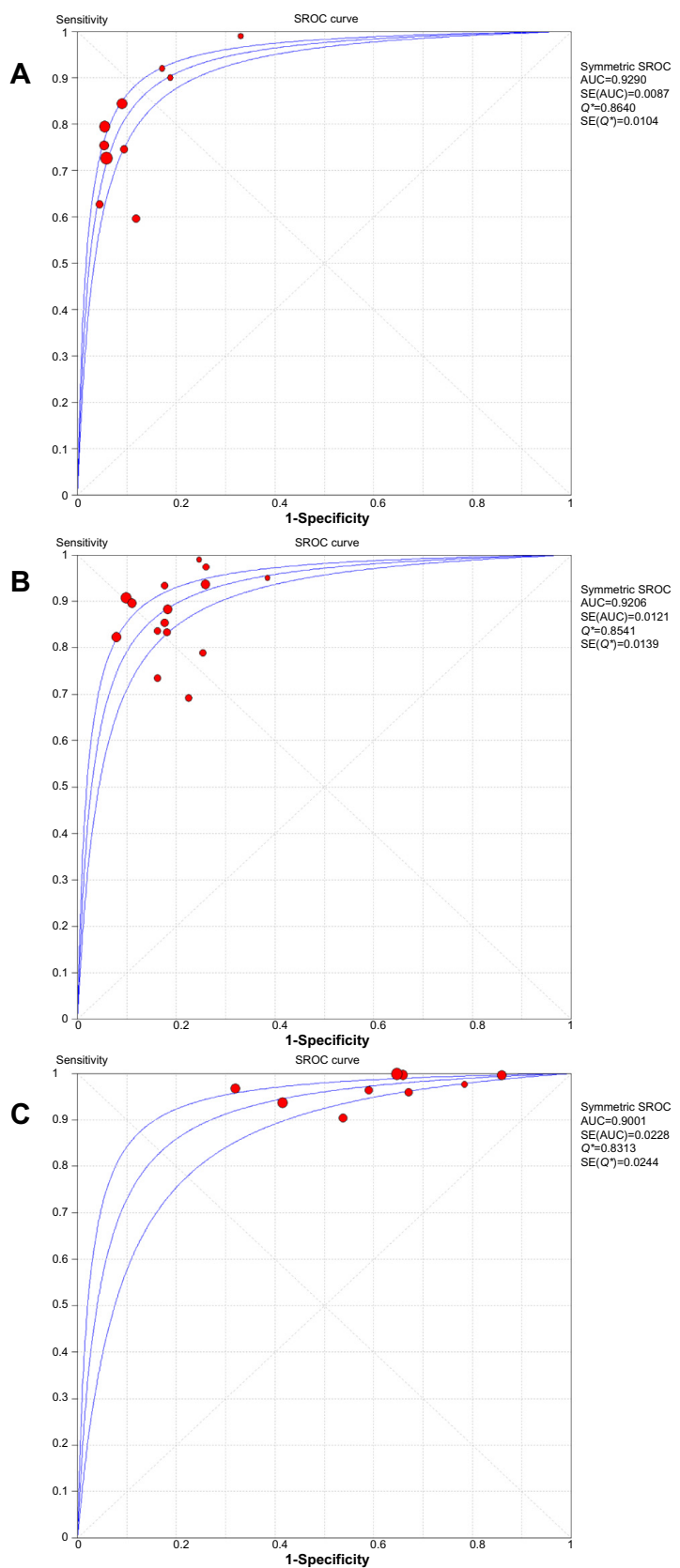

Figure 3 Summary receiver operating plots: (A) conventional troponin, (B) sensitive/high-sensitive troponin at 99th percentile cut-off, and (C) high-sensitive troponin at the level of detection.

Notes: AUC (A) versus (B) $(P=0.62)$, and $(\mathbf{A})$ versus $(\mathbf{C})(P=0.2344)$. Each dot represents study level estimate. The central curve represents the summary estimate of the AUC derived from the study level data, and the upper and lower curve represent its $95 \%$ confidence interval.

Abbreviations: AUC, area under the curve; SE, standard error; SROC, summary receiver operating curve.

data from Khan et al, were 0.91 (95\% CI: 0.89-0.93) and $0.67(0.63-0.70)$, respectively, as shown in Figure 4.

\section{Quality assessment}

The methodological quality summary based on the QUADAS questionnaire is shown in Figure S2. The majority of the studies were thought to have included a representative spectrum of patients presenting to the emergency department or admitted to the hospital, except for the studies by Aldous et al, ${ }^{12}$ Bhardwaj et al, ${ }^{23}$ Casals et al, ${ }^{15}$ and Schreiber et al, ${ }^{22}$ because of the use of a convenience sample, incompletely defined inclusion criteria, or unrealistic exclusion criteria. The index test was not blinded in the study by Christ et al. ${ }^{8}$ No studies reported intermediate or uninterpretable test results.

\section{Discussion}

The introduction of s/hsTrop assays with enhanced analytic performance, consistent with the recommendations of the $\mathrm{ESC} / \mathrm{ACCF} / \mathrm{AHA} / \mathrm{WHF}$ consensus statement, is considered a major advancement in cardiovascular medicine. These assays are being used in many parts of the world, and are awaiting approval in the US and recently became approved for use in Canada. There is no standardized definition for the term hsTrop assays in the current literature, and it has been used for assays with variable properties. Most experts advocate the use of the term "hsTrop assays" for the assays that detect cardiac Trop in the majority of the reference population. ${ }^{32}$ Optimal precision, ie, $\mathrm{CV}<10 \%$ at the 99th percentile as defined by the ESC/ACCF/WHF consensus document is another desired characteristic feature of hsTrop assays. These features make s/hsTrop assays more sensitive compared to conventional Trop assays, especially near the upper reference limit. In the absence of a widely accepted definition of high-sensitive assays, we included studies evaluating assays with LOD at $<99$ th percentile and $\mathrm{CV} \leq 10 \%$ at the 99th percentile to be consistent with the ESC/AHA/ACCF/WHF consensus statement.

The 99th percentile is the cut-off recommended by the Joint ESC/ACCF/AHA/WHF task force as the decision limit, in addition to a rise and fall pattern, for the diagnosis of AMI. Similar to clinical practice, this decision limit is not consistently used for conventional Trop assays by contemporary studies evaluating the accuracy of s/hsTrop for the diagnosis of AMI. ${ }^{5,6}$ As pointed out previously, ${ }^{32}$ we found that studies using a cut-off of $\mathrm{CV}<10 \%$ (which is achieved at a level greater than the 99th percentile for all of the included conventional assays) instead of the 99th percentile, reported a higher diagnostic accuracy for s/hsTrop assays at presentation, as reflected by a relative diagnostic odds ratio of 2.15 (Table 1B). Although DOR does not allow separate weighing of true and false positive rates, it appears logical that the use of a cut-off higher than the 99th percentile will decrease the true positive rate for AMI; this may therefore enhance the diagnostic accuracy of s/hsTrop on presentation. 

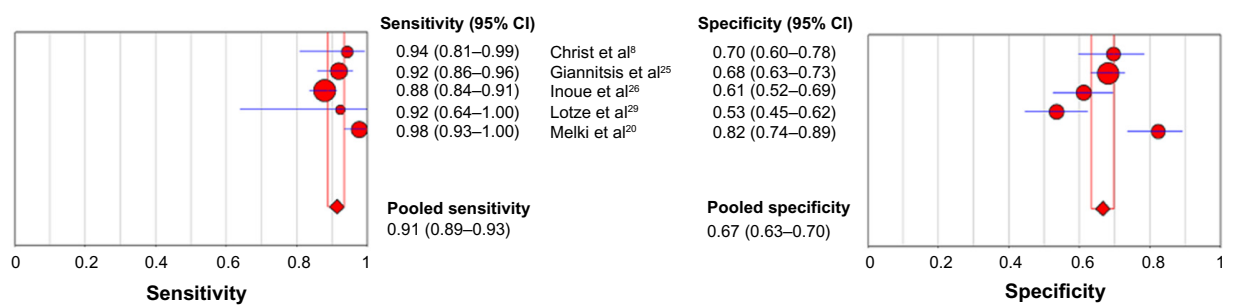

Figure 4 Forest plot showing pooled sensitivities and specificities for high-sensitive troponin T (Hoffman-La Roche Ltd) when high-sensitive troponin T assays were used in the reference standard.

Note: Data are rounded to two decimal points.

Abbreviation: $\mathrm{Cl}$, confidence interval.

Further, comparing the AUC of SROC for s/hsTrop and conventional Trop on presentation at the 99th percentile cutoff failed to show any difference in supporting the current recommendation of using the 99th percentile, instead of at a CV level of $<10 \%$, as the decision limit.

Some authors have suggested that using a novel cut-off at the LOD for hsTrop on presentation can be an effective rapid rule out strategy, which is often desired in the emergency room setting. ${ }^{7,8}$ As shown in Table 1, at this novel cut-off, $\mathrm{s} /$ hsTrop assays provide an excellent sensitivity of 0.97 . The negative predictive value will vary by the disease prevalence, but in general, may not reduce the historically reported rate of missed diagnosis of about $2 \% .{ }^{33}$ Also, it is important to note that excellent sensitivity for the diagnosis of AMI may not be used to rule out ACS. Although no data was available for the novel cut-off, at the 99th percentile, s/hsTrop assays had a sensitivity ranging from $0.56-0.77$; therefore, it certainly cannot be used as rapid rule out strategy underscoring the importance of complete clinical evaluation of the individual patient.

Evaluation of more sensitive assays against less sensitive reference standards is one of the limitations of the studies included in the primary analysis, as it may potentially inflate sensitivity with apparent loss of specificity. As Trop may be detected with s/hsTrop assays in some patients diagnosed as having unstable angina using conventional Trop assays, it may be useful to evaluate specificity for ACS rather than AMI. The specificity of s/hsTrop assays for ACS ranged 0.76-0.90 (Figure S1), which may not be an improvement over specificity for AMI (Table 1A). Furthermore, a systematic review of studies using s/hsTrop assays in the reference standard for the diagnosis of AMI (Table S2) shows that studies using very stringent exclusion criteria, ie, excluding all alternate diagnoses, cardiomyopathies, heart failure, etc, may achieve a specificity exceeding 0.9 . However, the studies with a more representative spectrum of the patient population using contemporary diagnostic methods have lower specificity (Figure 3). Prior studies have shown that ACS patients testing positive for Trop by conventional assays derive additional benefit from glycoprotein IIb/IIIA inhibitors and anticoagulant therapies. ${ }^{34,35}$ Similarly, these patients appear to benefit from invasive therapy as opposed to conservative management. ${ }^{36}$ However, it remains unknown if ACS patients testing positive with hsTrop assays but negative with conventional Trop assays will benefit from these therapies.

$\mathrm{s} / \mathrm{hs}$ Trop assays may detect elevation greater than at the 99th percentile in patients with non-ACS conditions including stable CAD and heart failure. ${ }^{37-39}$ Therefore, one of other major concerns with hsTrop assays is the false positive rates, which exceed $30 \%$ even when hsTrop assays were used in the reference standard (Figure 4). It is likely these patients who tested positive for elevated s/hsTrop in routine clinical practice will undergo additional testing that may not have been otherwise warranted. The cost incurred by this undesirable consequence of s/hsTrop assay use needs to be evaluated in future studies.

\section{Limitations}

This was a study level meta-analysis with significant heterogeneity among the studies not completely explained by meta-regression analysis. The power to detect statistically significant relationships between study level covariates such as the prevalence of CAD and inclusion of dialysis and diagnostic accuracy of s/hsTrop was limited due to the relatively small number of studies. The effect of time elapsed between symptom onset to presentation and diagnostic accuracy could not be explored in the present analysis.

\section{Conclusion}

s/hsTrop assays have excellent diagnostic accuracy for AMI on initial presentation at the currently recommended cut-off of 99th percentile. At a cut-off of LOD, s/hsTrop provides excellent sensitivity for AMI but may not be ideal for risk-free rapid exclusion for ACS. There is no conclusive evidence that s/hsTrop assays outperform conventional Trop assays when a cut-off of 99 th percentile is used for the latter. Studies evaluating clinical endpoints and cost-effectiveness 
are needed before accepting these assays in routine clinical practice.

\section{Disclosure}

The authors report no conflicts of interest in this work.

\section{References}

1. Centers for Disease Control and Prevention. National Hospital Ambulatory Medical Care Survey: 2009 Emergency Department Summary Tables. Atlanta, GA: Centers for Disease Control and Prevention. Available from: http://www.cdc.gov/nchs/fastats/ervisits. htm. Accessed May 19, 2014.

2. Wright RS, Anderson JL, Adams CD, et al. 2011 ACCF/AHA focused update of the Guidelines for the Management of Patients with Unstable Angina/Non-ST-Elevation Myocardial Infarction (updating the 2007 guideline): a report of the American College of Cardiology Foundation/American Heart Association Task Force on Practice Guidelines developed in collaboration with the American College of Emergency Physicians, Society for Cardiovascular Angiography and Interventions, and Society of Thoracic Surgeons. J Am Coll Cardiol. 2011;57(19):1920-1959.

3. Thygesen K, Alpert JS, White HD; Joint ESC/ACCF/AHA/ WHF Task Force for the Redefinition of Myocardial Infarction. Universal definition of myocardial infarction. $J$ Am Coll Cardiol. 2007;50(22):2173-2195.

4. Thygesen K, Alpert JS, Jaffe AS, et al; Joint ESC/ACCF/AHA/WHF Task Force for the Universal Definition of Myocardial Infarction. Third universal definition of myocardial infarction. Circulation. 2012;126(16):2020-2035.

5. Myocardial infarction redefined - a consensus document of The Joint European Society of Cardiology/American College of Cardiology Committee for the redefinition of myocardial infarction. Eur Heart J. 2000;21(18):1502-1513.

6. Keller T, Zeller T, Peetz D, et al. Sensitive troponin I assay in early diagnosis of acute myocardial infarction. $N$ Engl J Med. 2009;361(9): 868-877.

7. Body R, Carley S, McDowell G, et al. Rapid exclusion of acute myocardial infarction in patients with undetectable troponin using a high-sensitivity assay. J Am Coll Cardiol. 2011;58(13):1332-1339.

8. Christ M, Popp S, Pohlmann H, et al. Implementation of high sensitivity cardiac troponin T measurement in the emergency department. Am J Med. 2010;123(12):1134-1142.

9. Reichlin T, Hochholzer W, Bassetti S, et al. Early diagnosis of myocardial infarction with sensitive cardiac troponin assays. $N$ Engl J Med. 2009;361(9):858-867.

10. Zamora J, Abraira V, Muriel A, Khan KS, Coomarasamy A. MetaDiSc: a software for meta-analysis of test accuracy data. BMC Med Res Method. 2006;6:31.

11. Aldous SJ, Florkowski CM, Crozier IG, et al. Comparison of high sensitivity and contemporary troponin assays for the early detection of acute myocardial infarction in the emergency department. Ann Clin Biochem. 2011;48(Pt 3):241-248.

12. Aldous SJ, Richards M, Cullen L, Troughton R, Than M. Diagnostic and prognostic utility of early measurement with high-sensitivity troponin $\mathrm{T}$ assay in patients presenting with chest pain. CMAJ. 2012;184(5):E260-E268.

13. Apple FS, Smith SW, Pearce LA, Ler R, Murakami M. Use of the Centaur TnI-Ultra assay for detection of myocardial infarction and adverse events in patients presenting with symptoms suggestive of acute coronary syndrome. Clin Chem. 2008;54(4):723-728.

14. Apple FS, Pearce LA, Smith SW, Kaczmarek JM, Murakami MM. Role of monitoring changes in sensitive cardiac troponin I assay results for early diagnosis of myocardial infarction and prediction of risk of adverse events. Clin Chem. 2009;55(5):930-937.
15. Casals G, Filella X, Bedini JL. Evaluation of a new ultrasensitive assay for cardiac troponin I. Clin Biochem. 2007;40(18):1406-1413.

16. Eggers KM, Venge $P$, Lindahl B. High-sensitive cardiac troponin $T$ outperforms novel diagnostic biomarkers in patients with acute chest pain. Clin Chim Acta. 2012;413(13-14):1135-1140.

17. Freund $Y$, Chenevier-Gobeaux C, Bonnet $P$, et al. High-sensitivity versus conventional troponin in the emergency department for the diagnosis of acute myocardial infarction. Crit Care. 2011;15(3):R147.

18. Keller T, Zeller T, Ojeda F, et al. Serial changes in highly sensitive troponin I assay and early diagnosis of myocardial infarction. JAMA. 2011;306(24):2684-2693.

19. Kurz K, Giannitsis E, Becker M, Hess G, Zdunek D, Katus HA. Comparison of the new high sensitive cardiac troponin $\mathrm{T}$ with myoglobin, h-FABP and cTnT for early identification of myocardial necrosis in the acute coronary syndrome. Clin Res Cardiol. 2011;100(3):209-215.

20. Melki D, Lind S, Agewall S, Jernberg T. Diagnostic value of high sensitive troponin $\mathrm{T}$ in chest pain patients with no persistent ST-elevations. Scand Cardiovasc J. 2011;45(4):198-204.

21. Reiter M, Twerenbold R, Reichlin T, et al. Early diagnosis of acute myocardial infarction in patients with pre-existing coronary artery disease using more sensitive cardiac troponin assays. Eur Heart J. 2012;33(8):988-997.

22. Schreiber DH, Agbo C, Wu AH. Short-term (90 min) diagnostic performance for acute non-ST segment elevation myocardial infarction and 30-day prognostic evaluation of a novel third-generation high sensitivity troponin I assay. Clin Biochem. 2012;45(16-17):1295-1301.

23. Bhardwaj A, Truong QA, Peacock WF, et al. A multicenter comparison of established and emerging cardiac biomarkers for the diagnostic evaluation of chest pain in the emergency department. Am Heart $J$. 2011;162(2):276-282. e1.

24. Zuily S, Chenevier-Gobeaux C, Claessens YE, Wahbi K, Weber S, Meune C. High diagnostic performance of a high-sensitivity cardiac troponin $\mathrm{T}$ assay in patients with suspected acute coronary syndrome. Int J Cardiol. 2011;146(1):115-116.

25. Giannitsis E, Kehayova T, Vafaie M, Katus HA. Combined testing of high-sensitivity troponin $\mathrm{T}$ and copeptin on presentation at prespecified cutoffs improves rapid rule-out of non-ST-segment elevation myocardial infarction. Clin Chem. 2011;57(10):1452-1455.

26. Inoue $\mathrm{K}$, Suwa $\mathrm{S}$, Ohta $\mathrm{H}$, et al. Heart fatty acid-binding protein offers similar diagnostic performance to high-sensitivity troponin $\mathrm{T}$ in emergency room patients presenting with chest pain. Circ J. 2011;75(12):2813-2820.

27. Kelly AM. Performance of sensitive troponin assay in the early diagnosis of acute myocardial infarction in the emergency department. Emerg Med Australas. 2011;23(2):181-185.

28. Khan DA, Sharif MS, Khan FA. Diagnostic performance of highsensitivity troponin $\mathrm{T}$, myeloperoxidase, and pregnancy-associated plasma protein A assays for triage of patients with acute myocardial infarction. Korean J Lab Med. 2011;31(3):172-178.

29. Lotze U, Lemm H, Heyer A, Müller K. Combined determination of highly sensitive Troponin $\mathrm{T}$ and copeptin for early exclusion of acute myocardial infarction: first experience in an emergency department of a general hospital. Vasc Health Risk Manag. 2011:7:509-515.

30. Olivieri F, Galeazzi R, Giavarina D, et al. Aged-related increase of high sensitive Troponin $\mathrm{T}$ and its implication in acute myocardial infarction diagnosis of elderly patients. Mech Ageing Dev. 2012;133(5): 300-305.

31. Scharnhorst V, Krasznai K, van't Veer MV, Michels R. Rapid detection of myocardial infarction with a sensitive troponin test. Am J Clin Pathol. 2011;135(3):424-428.

32. Thygesen K, Mair J, Giannitsis E, et al; Study Group on Biomarkers in Cardiology of ESC Working Group on Acute Cardiac Care. How to use high-sensitivity cardiac troponins in acute cardiac care. Eur Heart J. 2012;33(18):2252-2257.

33. Pope JH, Aufderheide TP, Ruthazer R, et al. Missed diagnoses of acute cardiac ischemia in the emergency department. $N$ Engl $J$ Med. 2000;342(16):1163-1170. 
34. Hamm CW, Heeschen C, Goldmann B, et al. Benefit of abciximab in patients with refractory unstable angina in relation to serum troponin T levels. c7E3 Fab Antiplatelet Therapy in Unstable Refractory Angina (CAPTURE) Study Investigators. N Engl J Med. 1999;340(21): 1623-1629.

35. Lindahl B, Venge P, Wallentin L. Troponin T identifies patients with unstable coronary artery disease who benefit from long-term antithrombotic protection. Fragmin in Unstable Coronary Artery Disease (FRISC) Study Group. J Am Coll Cardiol. 1997;29(1):43-48.

36. Kleiman NS, Lakkis N, Cannon CP, et al; TACTICS-TIMI 18 Investigators. Prospective analysis of creatine kinase muscle-brain fraction and comparison with troponin $\mathrm{T}$ to predict cardiac risk and benefit of an invasive strategy in patients with non-ST-elevation acute coronary syndromes. J Am Coll Cardiol. 2002;40(6):1044-1050.
37. Korosoglou G, Lehrke S, Mueller D, et al. Determinants of troponin release in patients with stable coronary artery disease: insights from CT angiography characteristics of atherosclerotic plaque. Heart. 2011;97(10):823-831.

38. Ndrepepa G, Braun S, Mehilli J, et al. Prognostic value of sensitive troponin $\mathrm{T}$ in patients with stable and unstable angina and undetectable conventional troponin. Am Heart J. 2011;161(1):68-75.

39. Latini R, Masson S, Anand IS, et al; Val-HeFT Investigators. Prognostic value of very low plasma concentrations of troponin $\mathrm{T}$ in patients with stable chronic heart failure. Circulation. 2007;116(11):1242-1249. 


\section{Supplementary materials}

Table SI Characteristics of studies reporting diagnostic accuracy of high-sensitive troponin assays using conventional troponin in the reference standard

\begin{tabular}{llllll}
\hline Study & $\begin{array}{l}\text { Enrollment } \\
\text { period }\end{array}$ & $\begin{array}{l}\text { Sample } \\
\text { size }\end{array}$ & $\begin{array}{l}\text { Age } \\
\text { (years)* }\end{array}$ & Males (\%) & Inclusion criteria \\
\hline Aldous et al' & $2006-2007$ & 332 & 64.3 & 60.2 & $\begin{array}{l}\text { Consecutive patients attending ED and having } \\
\text { suspicion of ACS that serial EKG and Trop } \\
\text { were deemed necessary }\end{array}$ \\
\hline
\end{tabular}

$\begin{array}{llll}\text { Aldous et al }^{2} & 2007-2010 & 639 & 65\end{array}$

59.7

\begin{tabular}{|c|c|c|c|c|}
\hline Apple et $\mathrm{al}^{3}$ & NR & 371 & 54 & 60 \\
\hline Apple et $\mathrm{al}^{4}$ & $2005-2006$ & 381 & 54 & NR \\
\hline Body et $\mathrm{al}^{5}$ & 2006-2007 & 703 & 58.6 & 61.2 \\
\hline
\end{tabular}

Casals et al ${ }^{6} \quad \mathrm{NR}$

120

67.6

73

Christ et al $\quad 2009$

137

66

64

Freund et al ${ }^{9}$

2005-2007

317

57

65

Keller et al ${ }^{10}$

2007-2008

1,818

61.4

66.4

Keller et al"

2007-2008

1,818

61.4

66.4

Kurz et al 2008

Melki et $\mathrm{al}^{13}$

2006-2008

65.6

67

233

65

67
Consecutive patients $>18$ years with symptoms suggestive of ACS presenting to ED between 5.30 am and $8 \mathrm{pm}$

Consecutive patients presenting with symptoms suggestive of ACS admitted through the ED to rule in or rule out AMI

Patients who presented with symptoms suggestive of ACS and were admitted through the ED to rule in or rule out AMI

Patients $>25$ years presenting to ED and had chest pain within the previous 24 hours that the initial treating physician suspected may be cardiac in nature

Patients presenting with acute chest pain

Consecutive patients with acute chest pain of possible coronary origin presented to the ED

Patients admitted to coronary care unit with chest pain lasting $\geq 15$ minutes within the last 24 hours (FAST II-study), or the last 8 hours (FASTER I-study)

Consecutive patients $>18$ years presented to the ED with chest pain suggestive of ACS with the onset or peak within the previous 6 hours

All patients between 18 and 85 years presenting with acute angina pectoris or equivalent symptoms

All patients between 18 and 85 years presenting with acute angina pectoris or equivalent symptoms

Consecutive patients with symptoms suggestive of ACS admitted to the Chest Pain Unit Consecutive patients with chest pain or other symptoms suggestive of ACS within 12 hours admitted to coronary care unit 


\begin{tabular}{|c|c|c|c|}
\hline Exclusion criteria & Adjudication of diagnosis & s/hsTrop assay used & $\begin{array}{l}\text { Conventional Trop assay and } \\
\text { cut-off used }\end{array}$ \\
\hline $\begin{array}{l}<18 \text { years old, inability to obtain } \\
\text { frozen sample }\end{array}$ & $\begin{array}{l}\text { By two cardiologists based } \\
\text { on history, Trop and investigations } \\
\text { (including stress test and angiogram) } \\
\text { largely in accordance with ACC/AHA } \\
\text { guidelines and ESC/ACC/AHA/ } \\
\text { WHF redefinition of } \mathrm{MI}^{18}\end{array}$ & hsTrop T (Roche) & $\begin{array}{l}\text { Architect Trop I 2nd generation } \\
\text { (Abbott Laboratories) at } 0.028 \mu \mathrm{g} / \mathrm{L} \\
\text { (99th percentile) }\end{array}$ \\
\hline STEMI & $\begin{array}{l}\text { By one of the two physicians based } \\
\text { on Trop I plus rise or fall pattern } \\
\text { of at least } 20 \% \text {, objective evidence } \\
\text { of ischemia, or significant CAD } \\
\text { on angiogram }\end{array}$ & hsTrop T (Roche) & $\begin{array}{l}\text { Architect Trop I (Abbott } \\
\text { Laboratories) at } 0.03 \mu \mathrm{g} / \mathrm{L} \\
(\mathrm{I} 0 \% \mathrm{CV})\end{array}$ \\
\hline Follow-up information not available & $\begin{array}{l}\text { By records review in accordance } \\
\text { with ESC/ACC/AHA redefinition } \\
\text { of } M I^{18}\end{array}$ & $\begin{array}{l}\text { Advia Centaur Trop I } \\
\text { Ultra (Siemens } \\
\text { Healthcare Diagnostics) }\end{array}$ & $\begin{array}{l}\text { Dade Behring Dimension or Stratus } \\
\mathrm{CS}) \text { at } 0.1 \mu \mathrm{g} / \mathrm{L} \text { (99th percentile) }\end{array}$ \\
\hline Inability to obtain second sample & $\begin{array}{l}\text { By records review in accordance } \\
\text { with } E S C / A C C / A H A / W H F \\
\text { redefinition of } M I^{18}\end{array}$ & $\begin{array}{l}\text { VITROS Trop I-ES } \\
\text { (Ortho-Clinical } \\
\text { Diagnostics) }\end{array}$ & $\begin{array}{l}\text { Dade Behring Dimension or Stratus } \\
\mathrm{CS} \text { at } 0.1 \mu \mathrm{g} / \mathrm{L} \text { (99th percentile) }\end{array}$ \\
\hline $\begin{array}{l}\text { Renal failure requiring dialysis, } \\
\text { trauma with suspected myocardial } \\
\text { contusion, or another medical } \\
\text { condition mandating hospital } \\
\text { admission }\end{array}$ & $\begin{array}{l}\text { By two independent investigators } \\
\text { who had all clinical, laboratory, } \\
\text { and imaging data available for review, } \\
\text { largely in accordance with ESC/ACC/ } \\
\text { AHA/WHF definition of } \mathrm{MI}^{18}\end{array}$ & hsTrop T (Roche) & $\begin{array}{l}\text { 4th generation Trop } \mathrm{T} \\
\text { (Roche) at } 10 \mathrm{ng} / \mathrm{L} \text { (99th percentile) }\end{array}$ \\
\hline NR & $\begin{array}{l}\text { By clinical, EKG, and enzymatic } \\
\text { findings according to ESC/ACC } \\
\text { redefinition of } \mathrm{Ml}^{5}\end{array}$ & $\begin{array}{l}\text { Advia Centaur Trop } \\
\text { I Ultra (Siemens } \\
\text { Healthcare Diagnostics) }\end{array}$ & $\begin{array}{l}\text { AccuTnl Access } 2 \\
\text { (Beckman Coulter) } \\
\text { at } 0.09 \mu \mathrm{g} / \mathrm{L}(\mathrm{I} 0 \% \mathrm{CV})\end{array}$ \\
\hline NR & $\begin{array}{l}\text { By two independent consultants based } \\
\text { on history, Trop, and investigations } \\
\text { (including stress test and angiogram) } \\
\text { largely in accordance with ESC/ACC/ } \\
\text { AHA/WHF redefinition of } \mathrm{MI}^{18}\end{array}$ & hsTrop T (Roche) & $\begin{array}{l}\text { 4th generation Trop T } \\
\text { (Roche) at } 0.04 \mu \mathrm{g} / \mathrm{L}(10 \% \mathrm{CV})\end{array}$ \\
\hline STEMI & $\begin{array}{l}\text { By independent endpoint evaluators } \\
\text { in accordance with ESC/ACC/AHA/ } \\
\text { WHF redefinition of MII }\end{array}$ & hs Trop T (Roche) & $\begin{array}{l}\text { Stratus CS (Siemens Healthcare } \\
\text { Diagnostics) at } 0.07 \mu \mathrm{g} / \mathrm{L} \\
\text { (99th percentile) }\end{array}$ \\
\hline $\begin{array}{l}\text { Patients with acute or chronic } \\
\text { kidney failure requiring dialysis }\end{array}$ & $\begin{array}{l}\text { By two ED physicians after reviewing } \\
\text { all medical records from presentation } \\
\text { to } 30 \text { days in accordance with } \mathrm{ESCl} \\
\text { ACC/AHA/WHF redefinition of } \mathrm{MI}^{18}\end{array}$ & hsTrop T (Roche) & $\begin{array}{l}\text { Trop I (Siemens Healthcare } \\
\text { Diagnostics) at } 0.14 \mu \mathrm{g} / \mathrm{L}(\mathrm{I} 0 \% \mathrm{CV}) \\
\text { and Trop I (Beckman Coulter) } \\
\text { at } 0.06 \mu \mathrm{g} / \mathrm{L}(\mathrm{I} \% \% \mathrm{CV})\end{array}$ \\
\hline $\begin{array}{l}\text { Major surgery or trauma within } \\
\text { the previous } 4 \text { weeks, pregnancy, } \\
\text { intravenous drug abuse, and anemia } \\
\text { (hemoglobin level }<10 \mathrm{~g} / \mathrm{dL} \text { ) }\end{array}$ & $\begin{array}{l}\text { By two independent cardiologists } \\
\text { after reviewing all available clinical, } \\
\text { laboratory, and imaging findings in } \\
\text { accordance with current guidelines }\end{array}$ & $\begin{array}{l}\text { Advia Centaur Trop I } \\
\text { Ultra (Siemens } \\
\text { Healthcare Diagnostics) }\end{array}$ & $\begin{array}{l}\text { Trop } T \text { (Roche) at } \\
0.03 \mathrm{ng} / \mathrm{mL}(\mathrm{I} \% \mathrm{CV} \text { ) or Dimension } \\
\text { RxL Trop I (Siemens Healthcare } \\
\text { Diagnostics) } 0.14 \mathrm{ng} / \mathrm{dL}(10 \% \mathrm{CV})\end{array}$ \\
\hline $\begin{array}{l}\text { Major surgery or trauma within } \\
\text { the previous } 4 \text { weeks, pregnancy, } \\
\text { intravenous drug abuse, and anemia } \\
\text { (hemoglobin level }<10 \mathrm{~g} / \mathrm{dL} \text { ) }\end{array}$ & $\begin{array}{l}\text { By two independent cardiologists } \\
\text { based on all available clinical, } \\
\text { laboratory, and imaging findings } \\
\text { according to ESC/ACC/WHF } \\
\text { redefinition of } \mathrm{MI}^{18}\end{array}$ & $\begin{array}{l}\text { Architect STAT } \\
\text { hsTrop I (Abbott } \\
\text { Laboratories) }\end{array}$ & $\begin{array}{l}\text { Trop } T \text { (Roche) at } \\
0.03 \mathrm{ng} / \mathrm{mL}(10 \% \mathrm{CV}) \text { or Dimension } \\
\text { RxL Trop I (Siemens Healthcare } \\
\text { Diagnostics) } 0.14 \mathrm{ng} / \mathrm{dL}(10 \% \mathrm{CV})\end{array}$ \\
\hline STEMI, chronic kidney disease & $\begin{array}{l}\text { Using ESC/ACC/AHA/WHF } \\
\text { redefinition of } \mathrm{MI}^{18}\end{array}$ & hsTrop T (Roche) & $\begin{array}{l}\text { 4th generation Trop T (Roche) at } \\
0.03 \mathrm{~g} / \mathrm{L}(10 \% \mathrm{CV})\end{array}$ \\
\hline STEMI & $\begin{array}{l}\text { By two physicians with access } \\
\text { to all patients' data in accordance } \\
\text { with ESC/ACC/AHA/WHF } \\
\text { redefinition of MII }\end{array}$ & hsTrop T (Roche) & $\begin{array}{l}\text { 4th generation Trop T (Roche) at } \\
0.04 \mu \mathrm{g} / \mathrm{L}(\mathrm{I} 0 \% \mathrm{CV}) \text { or Stratus CS } \\
\text { Trop I (Dade Behring) at } 0.1 \mu \mathrm{L} / \mathrm{L} \\
(\mathrm{I} \% \% \mathrm{CV})\end{array}$ \\
\hline
\end{tabular}

(Continued) 
Table SI (Continued)

\begin{tabular}{llllll}
\hline Study & $\begin{array}{l}\text { Enrollment } \\
\text { period }\end{array}$ & $\begin{array}{l}\text { Sample } \\
\text { size }\end{array}$ & $\begin{array}{l}\text { Age } \\
\text { (years)* }\end{array}$ & Males (\%) & Inclusion criteria \\
\hline Reiter et al ${ }^{14}$ & $2006-2009$ & 1,098 & 64 & 67 & $\begin{array}{l}\text { Consecutive patients presenting to the ED } \\
\text { with chest pain suggestive of AMI with onset } \\
\text { or peak within the last I2 hours }\end{array}$ \\
& & & &
\end{tabular}

Schreiber et al $^{15} \quad$ 2005-2006

Studies reporting ACS only

Bhardwaj et al 2006

Zuily et al ${ }^{17}$

2009

87

60
49.2

53.8
Patients $>21$ years presenting to ED with suspected ACS during weekdays between 9 am and $5 \mathrm{pm}$

Patients $>21$ years presenting to ED with symptoms suggestive of ACS

Note: $*$ Mean/median.

Abbreviations: ACC, American College of Cardiology; ACS, acute coronary syndrome; AHA, American Heart Association; AMI, acute myocardial infarction; CAD, coronary artery disease; CV, coefficient of variance; ED, emergency department; EKG, electrocardiography; ESC, European Society of Cardiology; ESRD, end-stage kidney disease; s/hsTrop, sensitive/high-sensitive troponin; MI, myocardial infarction; NR, not reported; Trop, troponin; STEMI, ST elevation myocardial infarction; WHF, World Heart Federation; Roche, Hoffman-La Roche Ltd; Siemens, Siemens Healthcare Diagnostics. 


\begin{tabular}{|c|c|c|c|}
\hline Exclusion criteria & Adjudication of diagnosis & s/hsTrop assay used & $\begin{array}{l}\text { Conventional Trop assay and } \\
\text { cut-off used }\end{array}$ \\
\hline ESRD on dialysis & $\begin{array}{l}\text { By two independent cardiologists } \\
\text { based on review of all available } \\
\text { medical records in accordance } \\
\text { with ESC/ACC/AHA/WHF } \\
\text { redefinition of } \mathrm{MI}^{18}\end{array}$ & $\begin{array}{l}\text { hsTrop T (Roche) and } \\
\text { Trop I Ultra } \\
\text { (Siemens Healthcare } \\
\text { Diagnostics) }\end{array}$ & $\begin{array}{l}\text { Abott-Axsym Trop I (Abbott } \\
\text { Laboratories) at } 0.16 \mathrm{ng} / \mathrm{mL} \text {, } \\
\text { Accu Trop I (Beckmann Coulter) } \\
\text { at } 0.06 \mathrm{ng} / \mathrm{mL} \text {, or } 4 \text { th generation } \\
\text { Trop T (Roche) } 0.035 \mathrm{ng} / \mathrm{mL} \\
\text { (all } 10 \% \mathrm{CV} \text { ) }\end{array}$ \\
\hline STEMI & $\begin{array}{l}\text { By two authors based on clinical, } \\
\text { Trop, and imaging data in accordance } \\
\text { with ESC/ACC/AHA/WHF } \\
\text { redefinition of MI18 }\end{array}$ & $\begin{array}{l}\text { hsTrop I } \\
\text { (Singulex Erenna) }\end{array}$ & $\begin{array}{l}\text { Dimension RxL Trop I } \\
\text { (Siemens Healthcare Diagnostics) } \\
\text { I40 ng/L ( } 10 \% \mathrm{CV})\end{array}$ \\
\hline $\begin{array}{l}\text { Thrombolytic use, high output } \\
\text { state, cirrhosis, dialysis, symptoms } \\
\text { relief }>2 \text { hours, trauma, infection, } \\
\text { malignancy, cocaine use, acute } \\
\text { bowel or cerebral ischemia, } \\
\text { peripheral artery disease }\end{array}$ & $\begin{array}{l}\text { By investigators at each institution } \\
\text { and principal investigator after } \\
\text { reviewing medical records using } \\
\text { standard criteria recommended } \\
\text { by } A C C / \mathrm{AHA}^{19}\end{array}$ & $\begin{array}{l}\text { hsTrop I } \\
\text { (Singulex Erenna) }\end{array}$ & $\begin{array}{l}\text { Trop T (Roche) } \\
\text { at } 0.03 \mathrm{ng} / \mathrm{mL}(10 \% \mathrm{CV})\end{array}$ \\
\hline Cardiac arrest or STEMI & $\begin{array}{l}\text { By two cardiologists reviewing all } \\
\text { data in accordance with } \mathrm{ESC} / \mathrm{ACC} / \\
\text { AHA/WHF redefinition of } \mathrm{MI}{ }^{18}\end{array}$ & $\begin{array}{l}\text { hsTrop T } \\
\text { (Roche) }\end{array}$ & $\begin{array}{l}\text { Trop I (Siemens Healthcare } \\
\text { Diagnostics) I } 40 \text { ng/L (I0\% CV) }\end{array}$ \\
\hline
\end{tabular}




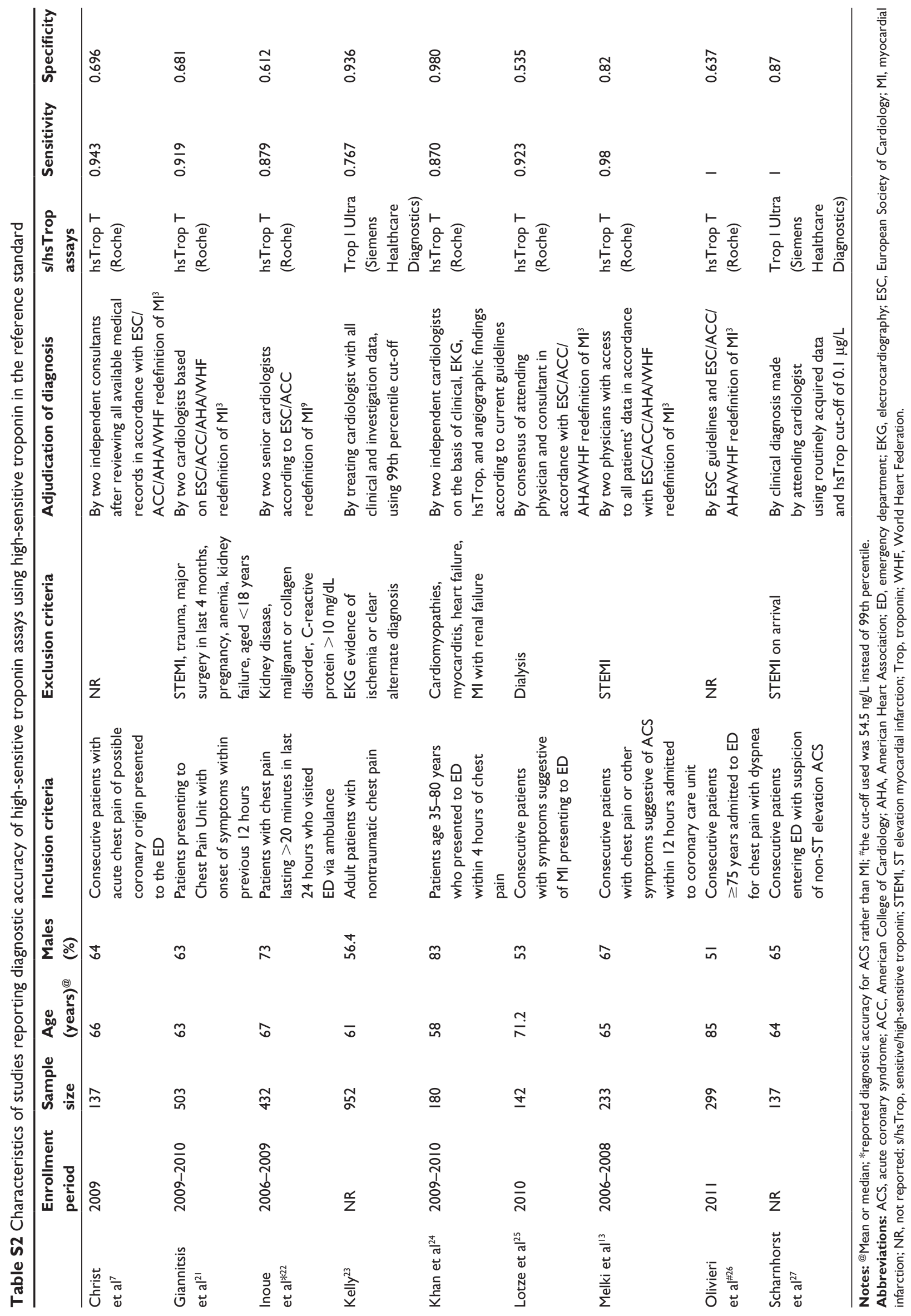




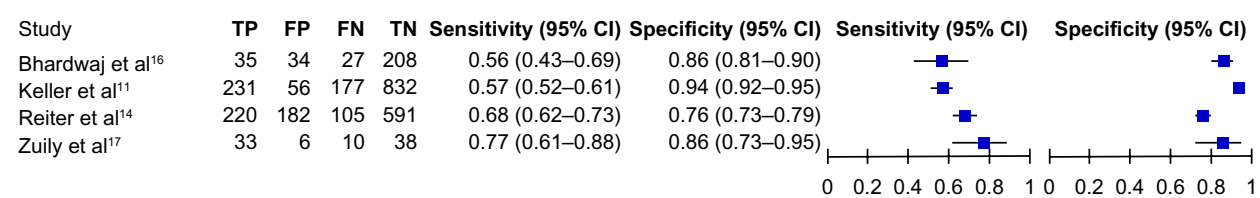

Figure SI Summary plot of individual studies reporting sensitivity and specificity for high-sensitive troponin assays at presentation for acute coronary syndrome. Abbreviations: $\mathrm{Cl}$, confidence interval; $\mathrm{FN}$, false negative; FP, false positive; TN, true negative; TP, true positive.

Representative spectrum?

Acceptable reference standard?

Acceptable delay between tests?

Partial verification avoided?

Differential verification avoided?

Incorporation avoided?

Reference standard results blinded?

Index test results blinded?

Relevant clinical information?

Uninterpretable results reported?

Withdrawals explained?

\begin{tabular}{|c|c|c|c|c|c|}
\hline & $0 \%$ & $25 \%$ & $50 \%$ & $75 \%$ & 100 \\
\hline Yes (high quality) & Unclear & & No ( & ality) & \\
\hline
\end{tabular}

Figure S2 QUADAS analysis of methodological quality of included studies.

Abbreviation: QUADAS, Quality Assessment tool for Diagnostic Accuracy Studies.

\section{References}

1. Aldous SJ, Florkowski CM, Crozier IG, et al. Comparison of high sensitivity and contemporary troponin assays for the early detection of acute myocardial infarction in the emergency department. Ann Clin Biochem. 2011;48(Pt 3):241-248.

2. Aldous SJ, Richards M, Cullen L, Troughton R, Than M. Diagnostic and prognostic utility of early measurement with high-sensitivity troponin $\mathrm{T}$ assay in patients presenting with chest pain. CMAJ. 2012;184(5):E260-E268.

3. Apple FS, Smith SW, Pearce LA, Ler R, Murakami M. Use of the Centaur TnI-Ultra assay for detection of myocardial infarction and adverse events in patients presenting with symptoms suggestive of acute coronary syndrome. Clin Chem. 2008;54(4):723-728.

4. Apple FS, Pearce LA, Smith SW, Kaczmarek JM, Murakami MM. Role of monitoring changes in sensitive cardiac troponin I assay results for early diagnosis of myocardial infarction and prediction of risk of adverse events. Clin Chem. 2009;55(5):930-937.

5. Body R, Carley S, McDowell G, et al. Rapid exclusion of acute myocardial infarction in patients with undetectable troponin using a highsensitivity assay. J Am Coll Cardiol. 2011;58(13):1332-1339.

6. Casals G, Filella X, Bedini JL. Evaluation of a new ultrasensitive assay for cardiac troponin I. Clin Biochem. 2007;40(18):1406-1413.
7. Christ M, Popp S, Pohlmann H, et al. Implementation of high sensitivity cardiac troponin T measurement in the emergency department. Am J Med. 2010;123(12):1134-1142.

8. Eggers KM, Venge P, Lindahl B. High-sensitive cardiac troponin T outperforms novel diagnostic biomarkers in patients with acute chest pain. Clin Chim Acta. 2012;413(13-14):1135-1140.

9. Freund Y, Chenevier-Gobeaux C, Bonnet P, et al. High-sensitivity versus conventional troponin in the emergency department for the diagnosis of acute myocardial infarction. Crit Care. 2011;15(3):R147.

10. Keller T, Zeller T, Peetz D, et al. Sensitive troponin I assay in early diagnosis of acute myocardial infarction. N Engl J Med. 2009;361(9): $868-877$.

11. Keller T, Zeller T, Ojeda F, et al. Serial changes in highly sensitive troponin I assay and early diagnosis of myocardial infarction. JAMA. 2011;306(24):2684-2693.

12. Kurz K, Giannitsis E, Becker M, Hess G, Zdunek D, Katus HA. Comparison of the new high sensitive cardiac troponin $\mathrm{T}$ with myoglobin, h-FABP and cTnT for early identification of myocardial necrosis in the acute coronary syndrome. Clin Res Cardiol. 2011;100(3):209-215.

13. Melki D, Lind S, Agewall S, Jernberg T. Diagnostic value of high sensitive troponin $\mathrm{T}$ in chest pain patients with no persistent ST-elevations. Scand Cardiovasc J. 2011;45(4):198-204. 
14. Reiter M, Twerenbold R, Reichlin T, et al. Early diagnosis of acute myocardial infarction in patients with pre-existing coronary artery disease using more sensitive cardiac troponin assays. Eur Heart J. 2012;33(8):988-997.

15. Schreiber DH, Agbo C, Wu AH. Short-term ( $90 \mathrm{~min}$ ) diagnostic performance for acute non-ST segment elevation myocardial infarction and 30-day prognostic evaluation of a novel third-generation high sensitivity troponin I assay. Clin Biochem. 2012;45(16-17):1295-1301.

16. Bhardwaj A, Truong QA, Peacock WF, et al. A multicenter comparison of established and emerging cardiac biomarkers for the diagnostic evaluation of chest pain in the emergency department. Am Heart J. 2011;162(2):276-282. e1.

17. Zuily S, Chenevier-Gobeaux C, Claessens YE, Wahbi K, Weber S, Meune C. High diagnostic performance of a high-sensitivity cardiac troponin $\mathrm{T}$ assay in patients with suspected acute coronary syndrome. Int J Cardiol. 2011;146(1):115-116.

18. Thygesen K, Alpert JS, White HD; Joint ESC/ACCF/AHA/ WHF Task Force for the Redefinition of Myocardial Infarction. Universal definition of myocardial infarction. J Am Coll Cardiol. 2007;50(22):2173-2195.

19. Wright RS, Anderson JL, Adams CD, et al. 2011 ACCF/AHA focused update of the Guidelines for the Management of Patients with Unstable Angina/Non-ST-Elevation Myocardial Infarction (updating the 2007 guideline): a report of the American College of Cardiology Foundation/American Heart Association Task Force on Practice Guidelines developed in collaboration with the American College of Emergency Physicians, Society for Cardiovascular Angiography and Interventions, and Society of Thoracic Surgeons. J Am Coll Cardiol. 2011;57(19):1920-1959.
20. Reichlin T, Hochholzer W, Bassetti S, et al. Early diagnosis of myocardial infarction with sensitive cardiac troponin assays. $N$ Engl J Med. 2009;361(9):858-867.

21. Giannitsis E, Kehayova T, Vafaie M, Katus HA. Combined testing of high-sensitivity troponin $\mathrm{T}$ and copeptin on presentation at prespecified cutoffs improves rapid rule-out of non-ST-segment elevation myocardial infarction. Clin Chem. 2011;57(10):1452-1455.

22. Inoue $\mathrm{K}$, Suwa $\mathrm{S}$, Ohta $\mathrm{H}$, et al. Heart fatty acid-binding protein offers similar diagnostic performance to high-sensitivity troponin $\mathrm{T}$ in emergency room patients presenting with chest pain. Circ J. 2011;75(12):2813-2820.

23. Kelly AM. Performance of sensitive troponin assay in the early diagnosis of acute myocardial infarction in the emergency department. Emerg Med Australas. 2011;23(2):181-185.

24. Khan DA, Sharif MS, Khan FA. Diagnostic performance of highsensitivity troponin $\mathrm{T}$, myeloperoxidase, and pregnancy-associated plasma protein A assays for triage of patients with acute myocardial infarction. Korean J Lab Med. 2011;31(3):172-178.

25. Lotze U, Lemm H, Heyer A, Müller K. Combined determination of highly sensitive Troponin $\mathrm{T}$ and copeptin for early exclusion of acute myocardial infarction: first experience in an emergency department of a general hospital. Vasc Health Risk Manag. 2011;7:509-515.

26. Olivieri F, Galeazzi R, Giavarina D, et al. Aged-related increase of high sensitive Troponin $\mathrm{T}$ and its implication in acute myocardial infarction diagnosis of elderly patients. Mech Ageing Dev. 2012;133(5): 300-305.

27. Scharnhorst V, Krasznai K, van’t Veer MV, Michels R. Rapid detection of myocardial infarction with a sensitive troponin test. Am J Clin Pathol. 2011;135(3):424-428.
Vascular Health and Risk Management

\section{Publish your work in this journal}

Vascular Health and Risk Management is an international, peerreviewed journal of therapeutics and risk management, focusing on concise rapid reporting of clinical studies on the processes involved in the maintenance of vascular health; the monitoring, prevention and treatment of vascular disease and its sequelae; and the involvement of

\section{Dovepress}

metabolic disorders, particularly diabetes. This journal is indexed on PubMed Central and MedLine. The manuscript management system is completely online and includes a very quick and fair peer-review system, which is all easy to use. Visit http://www.dovepress.com/ testimonials.php to read real quotes from published authors. 